\title{
Analysis of e-service in Public Complaints through Pro Denpasar Plus Application
}

\author{
I Putu Dharmanu Yudartha ${ }^{1, *}$
}

\author{
${ }^{1}$ Public Administration Department, Udayana University, Indonesia \\ *Corresponding author. Email: p.dharmanu@gmail.com
}

\begin{abstract}
The current era of digitalization encourages local governments to be more responsive in providing quality services. The phenomenon that occurs today, people begin to need efficient and effective services, one of which is through smartphone applications. This research aims to analyze complaint services through the Pro Denpasar Plus application through the concept of e-service. Denpasar city voters as the object of study is an innovation made in presenting application-based complaints, where not many other areas have done so. The method used is qualitative with a descriptive approach. This study uses secondary data through the study of literature, media, and documents. The data were analyzed using indicators in the concept of e-service quality from Zeithaml's thinking, namely efficiency, reliability, fulfilment and privacy. The results showed that not yet optimal of the reliability indicators. That is because only some people use that Application. The next indicator that is still not optimal in the Denpasar Pro Application, namely fulfilment. The condition occurs because of the large number of complaints in various fields, so the accuracy of the service becomes less appropriate. Meanwhile, bias efficiency indicators are said to be good in terms of ease in accessing the Pro Denpasar Plus application as well as the information displayed is good. The last indicator is privacy, which, based on the findings, shows that features ensure the confidentiality of the public who make complaints.
\end{abstract}

Keywords: e-service, complaints, analysis

\section{INTRODUCTION}

Public services are currently facing challenges in the covid-19 pandemic, where digital-based public services are a priority. It has long been a new paradigm of public service through an electronic government approach. E-Government refers to the use of information technology by agencies. The governments can change relationships with citizens, businesses, and other government units [1]. Public services based on information technology have become a necessity to be implemented by local governments. This condition is in line with the development of information technology that is so massive and has become a primary need for the community. Ease of access and use of information technology, especially for the community, will impact the demand for services with the same media or means.

Public services are a crucial issue today and a challenge, especially at the local level, where local governments must be at the forefront of providing services. To distinguish a service is categorized as a public service or not. There are several criteria for determining whether or not a public service is a public service. According to Stiglitz, goods and services that fall into the category of public goods or goods with high externalities usually cannot be held by corporations or handed over to the market because they cannot control who consumes such goods and services [2]. The second criterion for defining public services is the purpose of the delivery of goods and services. The provision of goods and services carried out to achieve the objectives and missions of the state, although the goods and services are private, can be said to be public services.

The services mandated in a constitution or legislation to meet citizens' basic needs are public. However, later different agencies that handle it do not eliminate the essence of the public service itself. So in this context, to try to analyze public services from the side of government bureaucracy, especially at the regional level. Rapid development in technology and information is pushing for a change in the essence of decentralization and regional autonomy. Local 
governments, in particular, must be able to encourage bureaucracy to be more responsive and accountable in providing services. But the dynamics that occur until now in public services tend not to be for the public or the public and not follow existing targets.

Denpasar City has become one of the municipalities that strive in positioning itself as a smart city. Making Denpasar City a smart city and the capital of Bali Province, Denpasar city made some breakthroughs or innovations. One form of the invention carried out by the city of Denpasar is the Denpasar Plus Pro Application. Pro Denpasar Plus program started in 2013 which aims to facilitate the complaint process by the public in various fields or problems [3]. In addition, Pro Denpasar Plus aims for people who do not know where to make complaints, inputs and complaints against public services in Denpasar City. Before the Pro Denpasar Plus program, complaints from the public were still made manually to every regional device organization, which took a long time. Pro Denpasar program was initially in the form of a website then developed into an application that downloads for the community. Using online media through the application, people can submit input and complaints freely (time, location and language). Denpasar Plus pro application provides space for the public to participate and is a means of media monitoring and evaluation of the achievements of development programs.

Technically, users access Denpasar pro through the website and can download it on the Playstore. Pro Denpasar Plus application needs to be analyzed from a unique public service perspective in the concept of eservice. E-Service quality becomes an essential aspect in assessing or evaluating services, significantly since the application of complaint services has long been flexed. E-Service can be understood that the public or the public must assess conformity with their expectations, especially the ease of getting the expected service [4]. According to Komara, understanding e-service is an electoral service by using media, such as the internet, to improve service quality [5]. The role actors or implementers of public services in providing services to the community and government support through the concept of e-government [6]. Therefore, the role of local governments in using the e-government approach in ensuring the quality of public services (e-service).

Problems faced in the implementation of Denpasar Plus Pro Application is that until now, in 2021, only about 10,000 have been downloaded. It is certainly not comparable to the number of residents in Denpasar City, especially smartphone users. Therefore, assessing or evaluating the Denpasar Pro Application is necessary, related to the problems and challenges faced. The author analyzes with an e-service approach, while there are several indicators. According to Zeithaml, Parasuraman, and Malhotra, there are four indicators. First, customers can easily and quickly access complaint services, and the application does not make it difficult for customers related to various features. Second, fulfilment, namely the availability of services or services needed by the community. Third, the availability or reliability of the application system used works correctly when and wherever it should. Fourth, Privacy and Security is concerned with the security of customer data guaranteed by the application service provider [7].

It other opinions according to Swaid and Wigand in measuring e-service quality through several dimensions. The first dimension is site usability, which is the user perception of the service related to ease in using the application and attractive appearance. The second dimension is the quality of information, which includes the accuracy of information provided to service users. The third dimension is reliability, which is the reliability of the application and the reliability of the service promised to the customer. The fourth dimension is responsiveness, which is the perception of consumers to get a response or help when there is a problem. The fifth dimension is insurance, which includes the trust that service users feel about the application and the relationship with the clarity and correctness of the information provided. The sixth dimension is personalization, which includes personalization to meet the needs of service users that suit their individual preferences [8]. These indicators become the basis in analyzing e-services in the Denpasar Plus Pro Application. Based on this, the author formulated a research question: how the quality of e-service in community complaints through the Pro Denpasar Plus application and what recommendations are appropriate for improving the service quality.

\section{METHOD}

This research uses qualitative and quantitative methods. The study conducts interviews first in qualitative data collection with the interview. They were then continued with quantitative analysis through a survey of selected respondents using random sampling. Researchers analyzed the quality of e-services on the Denpasar Plus Pro Application with four thought indicators from Zeithaml, Parasuraman, and Malhotra [9], i.e. efficiency, compliance, system availability, and privacy. They were then strengthened by public perception of The Denpasar Plus Pro Application. 


\section{DISCUSSION}

Denpasar City Government must be able to apply the concept of e-government in all fields, one of which is the field of service complaints. It becomes essential in improving or developing public service through internal government and external government involvement, namely citizens [10]. Pro Denpasar Plus application becomes a means that has been in developing public service in an e-government perspective. The use of The Denpasar Plus Pro Application as long as it is free, every user or prospective user can freely use various features of complaint services or other services. The cost incurred in using the Pro Denpasar Plus application locate in internet quotas charged to service users. It becomes one of the public service standards specifically to be accessible to the public; in addition, the Denpasar city government also provides free internet spots, especially in city parks. The goal is to make it easier for people who need free internet access. Any public complaint received by the Pro Denpasar Plus task force during business hours must immediately get a response or handling from the competent authorities. The answer to complaints and problems submitted by service users is to adjust to the management of regional device organizations in Denpasar City. Therefore, Pro Denpasar Plus operators must identify and clarify, and the conveyor announces the results to service recipients for a maximum of three to seven business days.

Community involvement becomes essential in making complaints, complaints, and reports related to public service performance issues in Denpasar City. The expected output is the increasing number of people who utilize mobile-based information technology and systems to evaluate development in Denpasar City. However, the findings show that the active users of the Denpasar Pro Application until October 2021 only amounted to 10,000 users. It is undoubtedly a weak side in the output of complaint services. The low production of the service impacts the achievement of the Denpasar Plus Pro Application service because there are still limited citizens who submit complaints and complaints related to the development and public services to the Denpasar City government. However, some things strengthen in the use of The Denpasar Plus Pro Application. The Pro Denpasar Plus application has been regulated in Denpasar Mayor Regulation number 45 of 2013 concerning handling community complaints. It makes the application of Pro Denpasar Plus application has the legal power and becomes the sustainability of future policies. Another factor that strengthens is the Denpasar Plus Pro Application to be one of Denpasar city's innovations in increasing transparency of local government violations and regional breakthroughs in improving the responsiveness of local government implementation.

Researchers also strengthened the study's findings by conducting a public survey assessing complaint services through the Denpasar Plus Pro Application. Researchers surveyed respondents domiciled in Denpasar City, the determination of respondents was done random sampling with the age of over 21 years. Determining the number of respondents, researchers use the sampling quota approach, which amounts to one hundred respondents. The first statement that survey researchers to respondents are respondents' intensity in accessing the Denpasar Plus Pro Application. The data obtained shows that most respondents stated that they never accessed (figure 1).

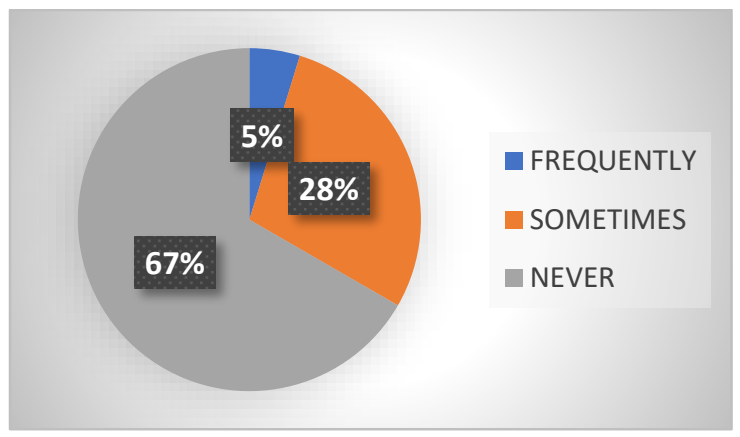

Figure 1. Percentage Respondent Intensity Accessing The Denpasar Plus Pro Application

The data above shows that it is necessary to increase socialization to residents in Denpasar City so that many residents have never accessed the Pro Denpasar Plus Application. On the other hand, the participation of citizens is also still low in providing an evaluation of the performance of services carried out by the city of Denpasar. Although it has been given intense socialization, citizens' awareness as supervisors of regional performance is still weak. It has an impact on the everyday use of The Denpasar Plus Pro Application. This condition is also in line with the findings that few residents still download the Pro Denpasar Plus application.

Another aspect that the author asked through the survey was the role of local governments in improving the handling of complaints against the performance of public services in Denpasar City. The data shows that respondents generally expressed Strongly Agree and agree, but quite a lot also stated that it was indifferent (Figure 2). 


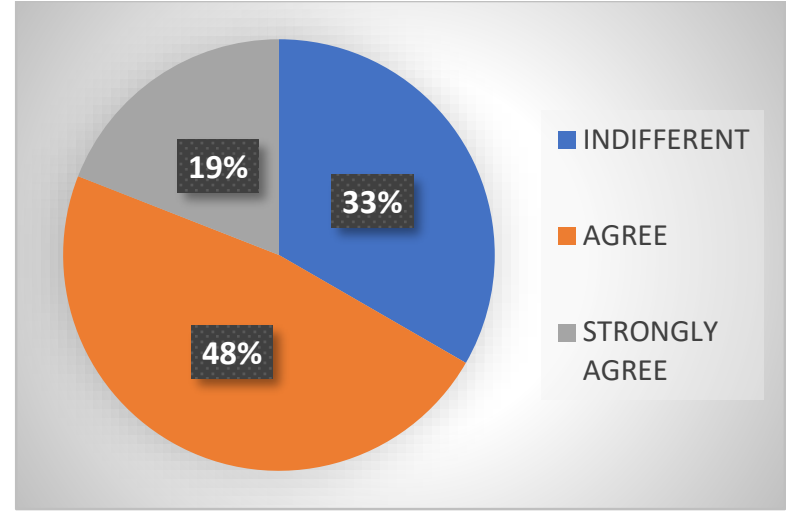

Figure 2. Percentage perception related to the regional government improves the complaints handling on public service performance

The above data certainly needs to be highlighted in evaluating the performance of public services, mainly based on complaint reports or complaints from citizens. Denpasar City Government is obliged to make changes to the delivery of these residents. It aims to improve the quality of public services, where the Denpasar Plus Pro Application becomes a means or medium for general evaluation and transparency. The demands and expectations of the community are getting higher and require ease in conveying it. It certainly requires the Denpasar City government to respond to community complaints. The data obtained show that the Denpasar City government has improved the response to criticism, demands and expectations of the community, with the highest percentage agreeing (Figure 3).

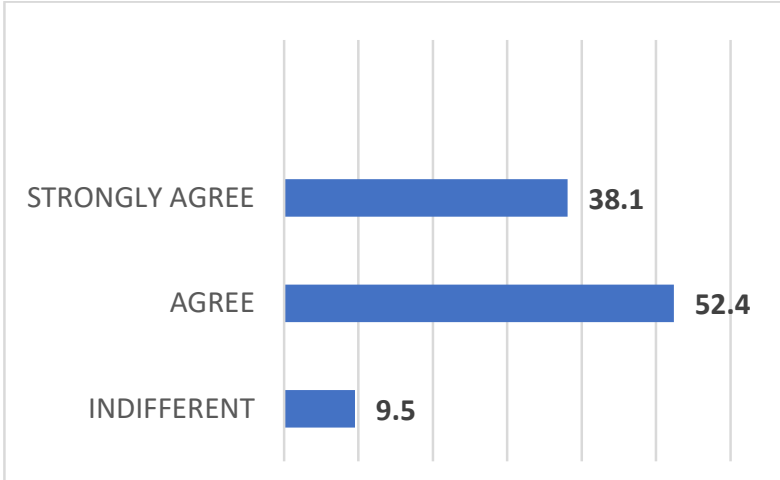

$\begin{array}{lllllll}0.0 & 10.0 & 20.0 & 30.0 & 40.0 & 50.0 & 60.0\end{array}$

Figure 3. Percentage of respondents related Local governments improving responses to criticism, protest actions, and community suggestions

The data above means that it is necessary to improve the response or any complaints and complaints and complaints of citizens or users of the service. Therefore, it is essential to consistently optimize the community's response to complaints and demands through the
Denpasar Plus Pro Application. It means that the speed of response and action becomes the primary value in improving the quality of Denpasar Plus Pro Application services. It then needs to be analyzed through the concept of e-service quality.

To analyze the quality of e-services, the author used the thinking of Zeithaml, Parasuraman, and Malhotra, namely efficiency, fulfilment of needs, reliability of application systems and privacy and security. If analyzed through efficiency indicators, the use of the Denpasar Plus Pro Application falls into the easy category. Its existing procedures or rules reinforce it in accessing the Denpasar Plus Pro Application. In addition, residents can report problems following the field, such as covid-19 problems, Whistleblowing, covid-19 counselling, public services, environment, infrastructure, traffic, Social and Labor, Regional Financial Management Clinic and other services. The diversity of features makes it easier for citizen complaint services, so residents or users can adjust the type of problem according to the available features.

The second indicator is the fulfilment of needs. It is related to the availability of services or services needed by the community. Pro Denpasar Plus application has been able to adjust to the dynamics in society, especially in pandemic situations. There are two features provided by the Denpasar Plus Pro Application related to the covid-19 pandemic. The two features are the covid-19 feature related to vaccine services and complaints related to health protocol violations. The covid-19 counselling feature is related to health consultations of the covid-19 pandemic.

The third indicator is the availability or reliability of application systems in terms of times and service access. The findings and data show that the Pro Denpasar Plus application has been connected with 52 agencies in the Denpasar City Government, regional companies, and villages. Of course, this further creates reliability in responding to every problem that is conveyed. In addition, access to the Denpasar Plus Pro Application can be done freely for service users who have registered or logged in on the application and website. Every citizen reported is always responded to by the operator in the "Follow Up" column. The Denpasar Plus Pro Application operator displays a follow-up form of citizen reports, photos of activities carried out and letters of reprimand to objects or subjects with a problem.

The last indicator is privacy and security. It relates to the guarantee of confidentiality of service users who file complaints and issues on the Application. In the Denpasar Plus Pro Application, there is a feature that can 
keep the name of the complainant secret, namely through the "secret" feature. The operator is not entitled to disseminate whistleblower information because it has been regulated in the mayor's regulations. In addition, there is also a whistleblowing feature. This feature allows residents or service users to convey something very confidential related to the cause or event.

\section{CONCLUSION}

In general, the quality of the e-service Pro Denpasar Plus Application is good if analyzed from the conceptual used by the author. Still, some factors can inhibit the low number of residents in Denpasar City who use, download and access the application. It needs to be an essential highlight amid the urgency of digital-based public services. The community must be willing and able to use the application to evaluate the performance of the Denpasar City government. In addition, the Denpasar city government needs to increase socialization and education to the public about the importance of the Application. The author also provides advice in expanding the use of The Denpasar Plus Pro Application. First, the local government made a circular letter to all government employees, teachers, business actors and other components to require downloading the Pro Denpasar Plus application. Second, The Denpasar Plus Pro Application is the primary condition for residents in Denpasar City to obtain public services in various fields. It means that residents must show they have downloaded the Denpasar Plus Pro Application to receive public assistance in Denpasar City. Later, Denpasar residents became aware and concerned about the problems in Denpasar City and became the primary partner in evaluating public policies and services.

\section{AUTHORS' CONTRIBUTIONS}

This paper aims to enrich public administration's understanding and knowledge, and scientific development, especially about e-service. This paper seeks for the central and local governments to innovate through applications that facilitate public services to the community. In addition, for students who want to conduct a study or research on e-service in the realm of government.

\section{ACKNOWLEDGMENTS}

The author thanked the faculty and Udayana university leaders who had provided opportunities to conduct research and the Denpasar city government, which provided data and information related to the Denpasar Plus Pro Application. Of course, thank you to the people in Denpasar City who have been respondents to this study.

\section{REFERENCES}

[1] B. Irawan, "Studi Analisis Konsep E-Government: Sebuah Paradigma Baru dalam Pelayanan Publik," J. Paradig., vol. 2, no. 1, pp. 54-68, 2013, doi: http://dx.doi.org/10.30872/jp.v2i1.351.

[2] A. Dwiyanto, "Membangun Sistem Pelayanan Publik," Populasi, vol. 13, no. 1, pp. 3-18, 2002.

[3] N. L. K. I. W. Sari, N. N. D. Pascarani, and I. D. A. S. Joni, "Pola Jaringan Komunikasi Internal Pemerintah Kota Denpasar dalam Mengelola Program PRO Denpasar +," E-jurnal Mediu., vol. 1, no. $7, \quad 2016$, doi: https://ojs.unud.ac.id/index.php/komunikasi/article /view/33617.

[4] D. David, "Pengaruh E-service Quality terhadap Loyalitas Pelanggan melalui Kepuasan Pelanggan pada Transportasi Online Grab," Agora, vol. 6, no. 2, pp. 95-100, 2018, [Online]. Available: http://publication.petra.ac.id/index.php/manajemen -bisnis/article/view/7720.

[5] A. Fahrika, N. Rachma, and A. R. Slamet, "Pengaruh Online Marketing Dan E-Service Quality Terhadap Loyalitas Dengan Kepuasan Sebagai Variabel Intervening Pada Online Shop Joyism Malang," J. Ilm. Ris. Manaj., vol. 8, no. 4, pp. 52-63, 2019, [Online]. Available: http://riset.unisma.ac.id/index.php/jrm/article/view $/ 2225$

[6] J. Holgersson, U. Melin, I. Lindgren, and K. Axelsson, "Exploring User Participation Practice in Public E-Service Development: Why, How and in Whose Interest?," Electron. J. e-government, vol. 16, no. 1, pp. 72-86, 2018, [Online]. Available: https://academicpublishing.org/index.php/ejeg/article/view/652.

[7] J. Riyanto, "E-Service Quality dan Pengguna GoCar di Kota Semarang," Serat Acitya, vol. 2, no. 1, pp. 70-93, 2021, [Online]. Available: http://jurnal.untagsmg.ac.id/index.php/sa/article/vi ew/2119.

[8] M. Rakhmat Romadhan, I. Indriastuty, and C Prihandoyo, "E-Service Quality Kepuasan Konsumen Melalui E-Commerce Terhadap Loyalitas Konsumen," J. GeoEkonomi, vol. 10, no. 2, pp. 150-163, 2019, doi: 10.36277/geoekonomi.v10i2.90. 
[9] T. Suryani, A. A. Fauzi, and M. Nurhadi, "the Determinant of Website Quality and E- Service Quality At Sme in Indonesia," J. Manaj. dan Kewirausahaan, vol. 22, no. 2, pp. 131-141, 2020, doi: 10.9744/jmk.22.2.131-141.
[10] J. Holgersson and F. Karlsson, "Public e-service development: Understanding citizens' conditions for participation," Gov. Inf. Q., vol. 31, no. 3, pp. 396-410, 2014, doi: 10.1016/j.giq.2014.02.006. 